\begin{tabular}{|c|c|}
\hline \multirow{3}{*}{ 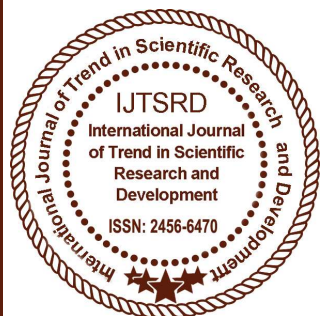 } & $\begin{array}{l}\text { International Journal of Trend in Scientific } \\
\text { Research and Development (IJTSRD) }\end{array}$ \\
\hline & International Open Access Journal \\
\hline & ISSN No: 2456 - 6470 | www.ijtsrd.com | Volume - 2 | Issue - 2 \\
\hline
\end{tabular}

\title{
A Comprehensive Study on Female Spouse Participation in Financial Communication during Family Financial Decision Making
}

\author{
Twinkle Jain \\ JRF, Faculty of Management Studies \\ Mohan Lal Sukhadia University, Udaipur, Rajasthan, India
}

\begin{abstract}
Money discussion is always a taboo in any relationship especially in that of marriage. Couples don't want to discuss much about financial matters which although is very important in this inflationary world. Sharing responsibilities within marriage is equally important as sharing financial responsibilities for the family. There cannot be bifurcations based on genders or any other categories. So, during family financial decision making, role of female spouse becomes equivalent important as she is both privileged $\&$ accountable for the repercussions of it as like her spouse. Involvement of female spouse in financial decisions starts with the step of involving her in financial communication related to it. Without communicating, how could one involve her? Thus, the whole study will focus on these female spouses' involvement in financial communication regarding their family financial decisions. Here, several implications of financial communication on a person's marital life, personality, status of involvement, family type, etc. will be discussed \& accordingly suggestions are recommended.
\end{abstract}

Keywords: Money discussion, Financial Communication, Family Financial Decisions, Female Spouse, Married life.

\section{INTRODUCTION}

Communication is a process by which people create \& share information with one another in order to reach common understanding (Rogers, 2000). It is the exchange of an information, thought or emotion between individuals or groups. Basically, it's an activity of conveying information to the other \& receiving its feedback.

Financial communication is also one of the important aspects of general communication. It refers to conversations between two or persons related to financial matters. This article is about financial communication attributes which is between a couple i.e. husband \& wife. Financial issues play a significant role in marital relationships. They do not add anything to beautify the relationship but its problems \& imbalances can mess up their marital life \& part ways for them. So, they need to be handled carefully. Mostly, couples do not communicate in general, which acts a back burner in their relationship (Shebib, 2016).

Talking about finances between the couples is considered as unusual. Husbands usually don't want to discuss monetary things with his wife or share a very little with her in maximum situations. So, this thing becomes a concern in this inflationary world where a single wrong financial decision can prove costly to the family. Every husband \& wife bears a burden of responsibility on behalf of their family both in physical terms \& monetary terms. So, their discussions \& mutual consent on financial outcomes are important.

Family communication is a dynamic twoway process, which is influenced by different factors such as personal characteristics of the individual family members; environment in which communication takes place; the participation of other people in communication; the quality and intensity of relations between people who are communicating; perceptive 
capability of individual participants of communication; timeframe of communication; family atmosphere; motivation for communication; standards to which communication is subjected (Gabura, 2012).

Conversations between a husband \& wife both lead to positive $\&$ negative results. They helps to know the thought process of each other \&let them face the expertise knowledge of the other. If communication done on financial decisions, it can also turn out positive or negative. Futris(2010) suggested two terms - constructive communication for Positive communication which includes appraisal, discussions, praises, compliments etc. while destructive communication for negative communication which includes cursing, blaming, complain, disapprove etc. each other for the decisions they had taken in past. Success of every marriage lies in constructive communication specially in financial matters.

So, to study the importance of financial communication for a couple regarding their future \& to know the level/status of involvement of female spouse in this during their family financial decision making, this research is done. The results \& conclusions presented in this study will help us to clear the objectives set $\&$ thus general implications can be drawn from it.

\section{Objectives of the Study:}

- To highlight the status of involvement of female spouse in the financial communication with her husband.

- To know the frequency of involvement of female spouse in financial communication with her husband.

- To study the impact of financial communication on marital relationship quality of husband \& wife.

- To highlight the importance of equal involvement of both spouses in better decision making.

- To check the awareness level of females regarding banking \& related transactions of her own account.

- To bring out the relation between family type $\&$ involvement level of females in financial decisions.

- To know the impact of educational background of female spouse on her involvement in family financial decision

\section{Review on proposed work already done:}

Seelig (2016) in his study had focussed on the communication factor among different couples types regarding their financial decisions. He examined the inter-relationship between relationship satisfaction, financial management \& financial communication.His findings were a great help to financial advisors, therapists etc. Through the study he highlighted the importance of productive money management \& financial communication on the committed relationships as it is a critical aspect in any relation.

Grobbelaar \& Alsemgeest (2016) through their study they had focussed on communication aspects of young couples which in certain negative situations can lead to stress in their marital life because they are new in reationship, less opeened to each other $\&$ had nil experience of managing finance as a couple.They had explained the whole chain of communication, arguments \& stress within a marriage on financial matters. They correlated the arguments on financial matters with the financial stress on couples.Debt was considered always a matter for arguments between couples.Their study suggested that increase in communication or discussion over financial matters with the spouse can definitely lead to fewer arguments.

Shebib(2016) through his study had contributed on the views of marital conflict due to financial communication problem in their married life.He discussed the importance of financial harmony among the couples to sustain their marriage life.According to him,partners in a marriage may have a different financial perspective from the other which may create destructive problems such as trust issues, lack of mutual understanding,hiding things from the other etc. in their married life resulting in reduction of their relational satisfaction. He concluded that the more the partners are in sync regarding monetry views,more they are satisfied with the financial communication occuring in their marriage.

Weeden (2015) in his study shows the link of money management on lifestyle of a person,arranging future security etc. for the family.According to him,marriage is a vital issue \& needs to be handle with care because couples do not want to discuss on money issues although when their marriage is failing on that part.So he highlighted the importance of pre- marital counselling on financial education.He discussed the 
elements of trust,mutual consent,better understanding,emotions,etc.He suggested on breaking cultural taboo by openly discussing money matters with each other.

Banovcinova \& Levicka (2015) in their study had very well shown the impact of family income on family communication. Their main focus of study was to link resource availablity \& commuinaction pattern followed by the couples. They had forwarded that low income families have negative associations with regards to family communication as compared to middled income or rich families.Family communication are affected by choice of worrds,expression \& mode of communication. They implicated for future study to be focussed on promoting more \& new communication patterns among these families so they could discuss more.

Young (2014) in his research had focussed on the family commuication factor on parenting \& its intergenerational transmission among the family members sepecially on couples.Acccroding to him, the values inherited from family whether possitive or negative continues till generations specially at the time of childhood.So,he studied the family communication patterns on behaviur,physcological outcomes, information

processing,family conflict,physical helath,self esteem,parent child relationship etc.He profounded the family communication pattern(FCP) theory which gave a blue print(idea) on how family members interact ,parental modeling with adult child behhaviour etc.

Romo(2013) through his study had made a lot of contribution on finanacial communication.He strongly supported the point that money matters should be oftenly discussed in family because financial choices affects families's stability \& quality of life in econmic terms.His study was based on the population of U.S. where he described financial communication with reference to financial literacy,financia managemnt,assest management,financial conflict etc.He also identified major obstacles in financial managemnt \& how it hampers financial communication in family.On the ending note, he suggested some strategies to be inculcated to improve communicationamong members of the family so that financial managementcould became successfull.

Agrawal \& $\operatorname{Garg}(2012)$ in their study have thrown light on communication with others in social context.Their study was mainly based on organisational communiacation \& its bifercated requiremnt as per various departments preent in that organisation. Time to time communication,sufficient interaction with the mangers, accurate flow of information are the important factors which play vital role in facilitating communication. They concluded on the note that every place wheather organisation or family, 2 way commuincation is important from both the parties.

Peterson \& Green(2009) in their study has highlighted the importance of effective communication on building a strong bond between the family members because it's the only source through which they can express their needs,wants,relationships etc.He along with other reserachers have discovered a strong link between commuincation \& family relationship satisfaction.The key factors behind all of them are the time they spent together,open \&direct communication between them, honesty in communication,environmnet during the communication,

Mugenda, Hira, \& Fanslow (1990) also assessed the inter linkage between communication,money management, satisfaction with financial staus \& quality/standard of life.According to them,financially literate couples discuss more on finnacial matters \& they are more satisfied with their decisions at theh end of the day.Even their demographic factors affect their standard \& quality.

On the basis of above literature reviewed the following things can be implicated:-

1. Financial communication between husband \& wife is the mediating factor between financial management \& their relationship satisfaction. How one communicates to another, his tone of expression, his/her importance etc. play an important role towards their ultimate relationship satisfaction.

2. Problems in financial management due to wrong decisions can cause stress in their life. However, with mutual trust, constructive communication, respect giving to the other, mutual decision making, etc. can improve the situation.

3. Sync with wife's point of view, her feelings consideration enhances a women's personality $\&$ boosts confidence in her regarding financial decision making.

4. Young married couples are more prone to wrong financial decisions are they are new in 
their relation \& not well ware with the other's viewpoints which can bring problems in their life to some extent.

5. Financial Values of family also play prominent role in financial management of the family \& thus results arrive accordingly.

6. Family's environment also impact the communication patterns between the spouses as the culture in which they are gown up encourages ore discourages from sharing financial decisions with the other spouse.

7. Wrong decisions or negative communication can arouse stress in marital life which further can hamper their relation.

\section{Research Methodology \& Analysis Technique:}

This study is based on Exploratory Research Design that aims to identify the participation of female spouse in financial communication during the family financial decision making. A questionnaire has been designed to know the frequency of their participation in financial communication with their husbands \& their status of involvement in their family regarding this.

First part of the questionnaire contains information regarding the demographics of female spouse such as name, age, years of marriage, educational qualifications, family type etc.
Second part has a series of close ended indirect questions which were designed in order to know the frequency or involvement in their family financial decision making through financial communication.

Third part consist of open ended question to know the personality development changes a women needs to bring in herself in order to be a prominent part of their financial decisions \& their expectation from their husband so that they understand their importance.

The data was collected through filling of questionnaire prepared by Google Forms \& were mailed to the respondents. Around 100 ladies were approached for this purpose out of which 80 were finalized.

For the purpose of data -

1. Presentation- Charts were used .

2. Analysis-SPSS tool \& Ms-Excel were used \& 7 hypotheses were framed.

3. Interpretation-Results obtained through above tools were presented.

\section{Data Analysis \& Interpretation:-}

After getting the questionnaire filled by the respondents the data was summarized \& now presented as follows-

\section{a. Educational Qualifications of Respondents-}

\begin{tabular}{|l|l|l|l|l|l|l|}
\hline Particulars & Professional & $\begin{array}{l}\text { Post } \\
\text { Graduate }\end{array}$ & Graduate & $\begin{array}{l}\text { Senior } \\
\text { Secondary }\end{array}$ & Secondary & Total \\
\hline No. & 12 & 46 & 15 & 6 & 1 & $\mathbf{8 0}$ \\
\hline
\end{tabular}

\section{Educational Qualifications}

- Secondary $\square$ Senior Secondary $\quad$ Graduate $\quad$ Post Graduate $\quad$ Professional

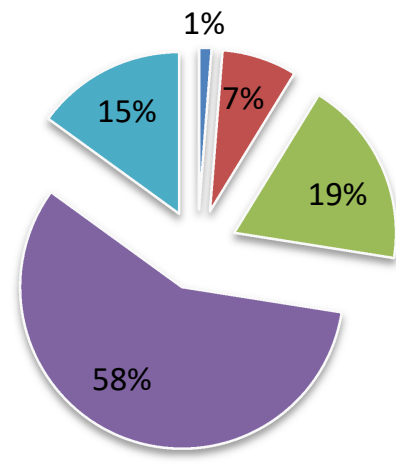


International Journal of Trend in Scientific Research and Development (IJTSRD) ISSN: 2456-6470

b. Frequency of Involvement of Female Spouse in Financial Communication-

\begin{tabular}{|c|c|c|c|c|c|c|}
\hline Particulars & $\begin{array}{c}\text { Very } \\
\text { Often }\end{array}$ & Often & Sometimes & Rare & $\begin{array}{c}\text { Very } \\
\text { Rare }\end{array}$ & $\begin{array}{c}\text { Total } \\
\text { No. }\end{array}$ \\
\hline
\end{tabular}

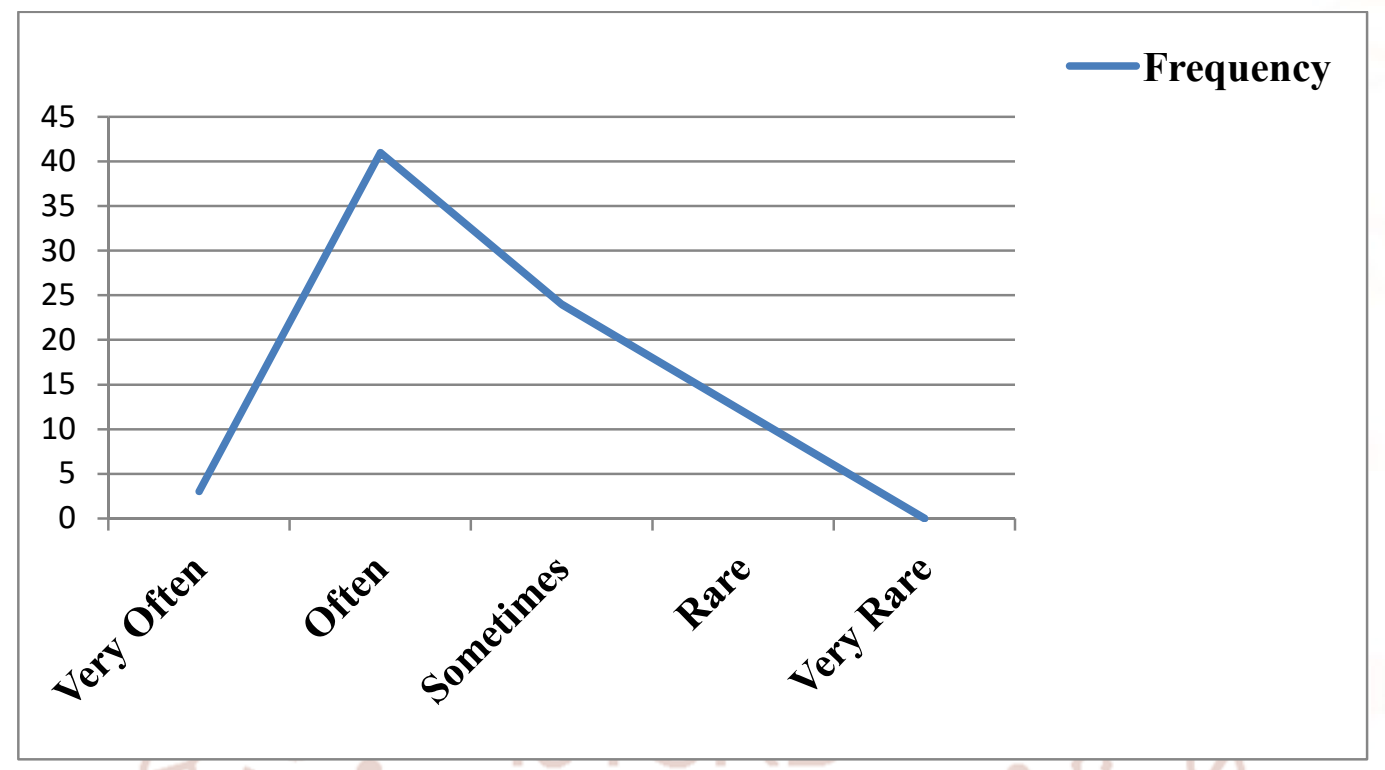

c. Status of Involvement-

Here, a bar chart is created in order to represent the status of female spouse involvement in financial communication regarding various things such as-

\begin{tabular}{|l|l|l|l|l|l|l|}
\hline Particulars & Highest & High & Neutral & Low & Lowest & Total \\
\hline $\begin{array}{l}\text { Importance given to } \\
\text { her view points }\end{array}$ & 13 & 45 vel & 14 enen & 7 & 1 & $\mathbf{8 0}$ \\
\hline $\begin{array}{l}\text { Positive effect on } \\
\text { their relationship }\end{array}$ & 44 & 24 & 5 & 5 & 2 & $\mathbf{8 0}$ \\
\hline $\begin{array}{l}\text { Mutual decision } \\
\text { making }\end{array}$ & 65 & 14 & 1 & 0 & 0 & $\mathbf{8 0}$ \\
\hline $\begin{array}{l}\text { Setting future goals } \\
\text { together }\end{array}$ & 29 & 30 & 16 & 2 & 3 & $\mathbf{8 0}$ \\
\hline
\end{tabular}

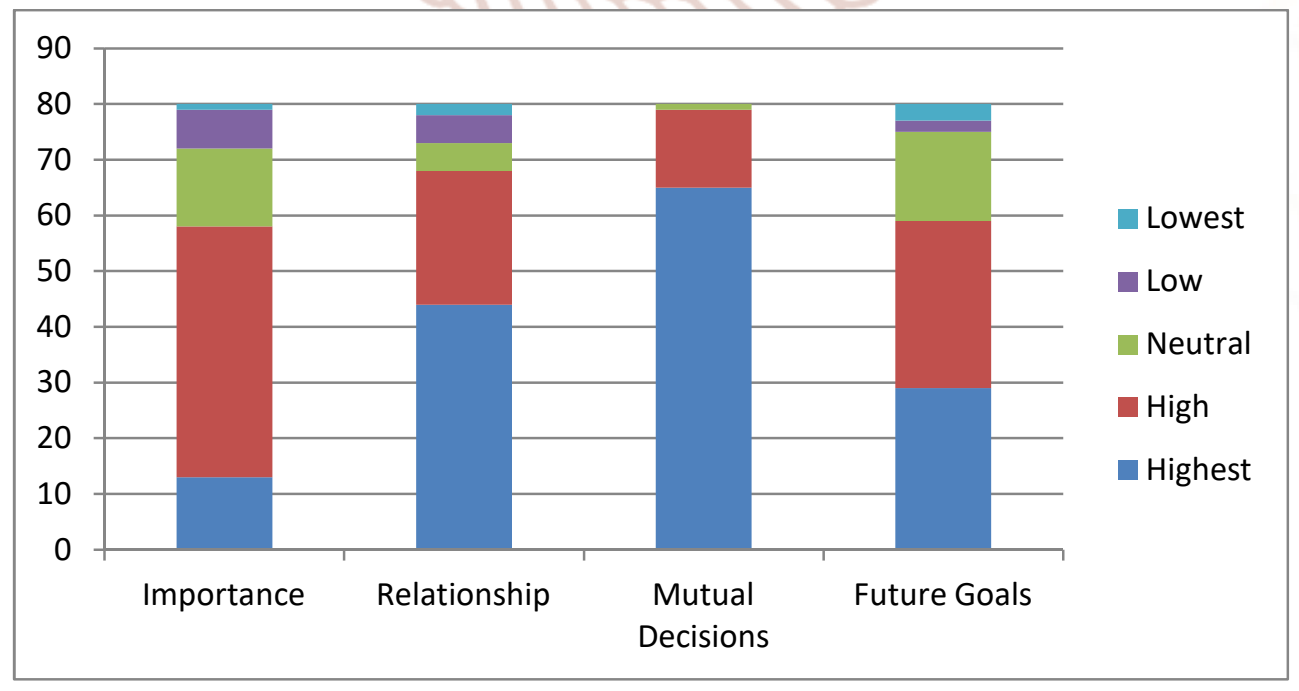




\section{d. Hypothesis Testing \& its interpretation-}

For the purpose of testing,5 null \& 2 alternative hypothesis were framed to verify the data. Here, t test, chi square test \& correlation coefficient techniques were applied to test the hypotheses.

\section{$\mathrm{H}_{1}$-There is no significant association of having a bank account $\&$ being aware about its status or day to day transactions}

I do not find any significant relation between females holding bank accounts in their name \& being aware about its current status or transactions proceeded through chi square test where chi square value is 1.71 $\& \mathrm{p}$ value $(\alpha)$ at significance is 0.679 .These figures imply that in maximum cases no matter there are bank accounts in the name of their spouse, but its whole management is there in the hands of their husbands. The reason may be lack of their keen interest, weak educational background or husband's dominant nature.

\section{$\mathrm{H}_{2}$-There is no significant difference between discussion \& conflict during financial communication between the couple}

With the available data after analysing, I found out that there is no significant difference between discussion \& conflict during financial communication through the use of $t$ test. The values obtained were $t$ value $=1.31 \& \mathrm{p}$ value $(\alpha)=0.194$ which states that I failed to reject the null hypothesis. Discussion \& arouse of general conflicts are the faces of a same coin \& heated discussions often generate conflicts.

$\mathrm{H}_{3}$-There is positive relationship between mutual decision making \& improvement in marital relationship quality

Here, after analysing the two variables I concluded that both are strongly related with each other through co-relation coefficient which came to be $0.824 \&$ it was significant at 5\% level. Mutual Decisions are always better as compared to taken by single ones. They generate feeling of trust upon each other, boost the confidence level on other's decision which are very important to run a successful marriage.

$\mathrm{H}_{4}$-There is positive relation between constructive financial communication \& enhancement of marital relationship quality
After calculating the significant correlation coefficient, the value obtained was 0.77 which is significant at 5\% level. Here, it can be concluded that more the constructive financial communication between the couples more the quality of their relationship enhances. Constructive communication promotes open \& positive communication, arouse confidence on each other, and define other's viewpoints without arguments etc. which intensifies each other love \& make it last longer.

\section{$\mathrm{H}_{5}$-There is no significant impact of experience} earned by continuous home management $\&$ uses it for present money management tips for the family

After reviewing the data for the above two variables value obtained through $t$ test were $t$ value $=2.31 \& p$ value $(\alpha)=0.023$ which is lower than significant value of 0.05 or $5 \%$ level which tends to reject the hypothesis. Here, it becomes quite self-evident that the experience earned through managing money all over the years has improved her techniques which are benefiting \& will benefit the family regarding the money resource management with limited sources.

$\mathrm{H}_{6}$-There is no relation between educational background (weak or strong) \& involvement for the financial communication

During the analysis of data for the above hypothesis, the value obtained through $t$ test were $t$ value $=7.71 \&$ $\mathrm{p}$ value $(\alpha)=0.000$ which is lower than significant value at $5 \%$ level of significance. Here, the hypothesis tends to be rejected \& proves that educational qualification of females affects their participation in financial decision making. In maximum cases, strong educational background prompts more involvement in communication with the spouse $\&$ family on financial matters.

\section{$\mathrm{H}_{7}$-There is no role of family type \& involvement/importance of females during} financial communication

When the data was analysed for the above variables through $t$ test, the value obtained for $p$ value $(\alpha)$ is 0.00001 which is lower than significant value of 0.05 which clearly depicts that the hypothesis stands rejected \& the family type impacts the involvement of female spouse during financial communication. During the surveys, it was cleared that joint families discourages participation of female spouses due to 
presence of elder members of family while nuclear family promotes equal involvement of both the spouses during any decision.

\section{Results \& Conclusions}

After getting the forms filled, coding them, analysing $\&$ interpreting them following conclusions were made-

a. Money discussion is considered as a taboo in Indian couples\& they still can't discuss it freely in initial years of their marriage. However, things gets easy when they become comfortable with each other \& starts discussions \& value each other viewpoints.

b. Education plays an important role in the participation of females during financial communication. Husbands are quite judgemental about her spouse's participation as according to them if she is well educated she could give valuable suggestions otherwise not. However, less educated females are also expert in their home management $\&$ needs to be given importance.

c. In this $21^{\text {st }}$ Century, financial communication between the couples has increased. Now, mostly both the spouses discusses things before taking any financial decision. But the situation is not same for all. Many females still fight for their role $\&$ importance in many houses just for the reason they do not earn. Earning is still considered to be the criteria for discussing things with her.

d. Mutual decision making, Importance to wife's advices, setting future goals together etc. definitely increases the compatibility between the couples \& things like this act as marriage boosters. Maximum ladies agree to these points \& want to include in their lifestyle.

e. Having a bank account is the need for this digital world but it doesn't guarantees its full knowledge to its owner. The same case is with the respondents or with maximum ladies in general .They hold bank accounts but maximum of them are not aware about its status, operations etc. For this they are either dependent on their husbands or children .After analysing its reason, it was confirmed that husband's dominant nature ,lack of their keen interest to teach them, lack of interest on part of females, weak educational background, less market knowledge were behind it etc. are some responsible factors. f. Discussions \& arouse of general conflict during financial communication are very common. Little misunderstanding, dominance over the other, neglect of others feelings etc. maybe there but these things should not discourage financial communication between them. Discussions if turned up negative then only they lead to conflicts otherwise not.

g. Discussions if patiently done can always prove right as they lead to mutual decisions where both husband \& wife are satisfied with the decision they had taken. Even it gives time to rethink upon the matter \& prevents hasty \& wrong decision because it's human nature that could make mistakes.

h. Mutual decisions making on financial matters is a positive feature of home management \& this generates frequent discussion between the two where the two openly shares their ideas with each other \& learn from the other's expertise. This brings a beautification in their relation \& improves their relationship quality over the time \& makes them integral part of each other.

i. Constructive financial communication act as strong pillar of the institution of marriage where both husband \& wife are dedicated foe each other. Involvement of females with the matters related to finance that too for her family boosts confidence in her personality \& makes deeply attached with the family. Secondly, this also improves the quality of the married life they are living.

j. Money management over the years \& learning from the past mistakes definitely builds up a good experience in females regarding the financial economy of her home. Using them to improve the techniques of present money management proves her to be better home manger. So, her decisions really became important for the betterment of family.

k. Sometimes, educational background became a barrier for her in involvement for the financial decision just for the reason she is imagined that she may not understand things, not give useful suggestions or there is no contribution oh her in income of family. But the situation in reality can be different. She can be we'll rich with the knowledge \& experience of home management \& concerns for family where an educated person gets defeated.

1. Family type of a lady may impact her involvement with her spouse during financial conversations as 
International Journal of Trend in Scientific Research and Development (IJTSRD) ISSN: 2456-6470

she is considered a last person to be included in it. Elder members of joint family specially father-inlaw, mother-in-law, other in laws can exclude her intentionally or non-intentionally presence where nuclear family promotes her involvement with financial decisions more as there are less people to discuss or interfere.

\section{Suggestions}

- Money discussions should be frequent between a couple because home management is a joint effort $\&$ both are equally important for its success or failure.

- No matter who is earner for the family, female spouse should be given equal opportunity for involvement in financial decision made for the family \& this can start through initiating financial communication with her.

- Education should not always be considered as judgemental criteria for her involvement in communication on financial matters. 1 Her experience \& money management tips should also be considered.

- Females holding bank accounts should be properly aware about its status \& learn to operate it. She should be least dependent on others regarding it operations \& take keen interest to learn about it.

- Ladies who don't have an bank account should go for it. Now, many government schemes are based on female family member \& the amount is directly transferred in their accounts \& thus they can be benefitted from it. Secondly, by operating it they can become more knowledgeable \& expertise.

- Mutual decision making are always better \& should be more promoted.

- With the fear of having conflicts, a couple can't put off the discussions with each other during financial conversations.

- Joint families should also encourage more female participation in financial communication before taking any decision,.

\section{Bibliography}

1) Agrawal, D. S., \& Garg, D. A. (2012). The Importance of Communication within Organisation:A Research on 2 Hotels in Uttarakhand. IOSR Jopurnal of Buisness \& Management, 40-49.

2) Banovcinova, A., \& Levicka, K. (2015). The Impact of the Financial Income on the Family
Communication. Revista Romaneasca Pentru Educatie, 35-46.

3) Bhanawat, S. (2016). Statistics for Managers. Udaipur.

4) Chawla, D., \& Sondhi, N. (2011). Research Methodolgy:Concepts \& Cases. New Delhi: Vikas Publishing House.

5) Cooper, D. R., Sharma, J. K., \& Schindler, P. S. (2012). Buisnesss Research Methods. New Delhi: McGraw Hill Education(India) Private Limited.

6) Grobbelaar, C., \& Alsemgeest, L. (2016). The Relationship between Spousal Communication and Financial Arguments and Stress between Young Married Couples. Journal of Social Science.

7) Gupta, S. (2015). Buisness Statistics.

8) Kothari, C. (2009). Research Methodolgy:Methods \& Techniques. New Age Publishers.

9) Mugenda, O. M., Hira, K. T., \& Fanslow, M. A. (1990). Assessing thr Casual Relationship among Communication,Money MAnagement

Practises,Satisfaction with Financial Status,and Satisfaction with Quality of Life. Lifestyles:Family \& Economics Issues.

10) Peterson, R., \& Green, S. (2009). Families First Keys to $\bigcirc$ Successful Family Functioning:Communication. VCE Publications.

11) Rogers. (2000). Communication.

12) Romo, L. K. (2013). In This day \& Age,You Just Don't Know:An Examination how People inRomantic Relationships Use Communication to Manage Financial Uncertainity. Austin.

13) Shebib, S. J. (2016). Financial Conflict Messages and Marital Satisfaction:The Mediating Role of Financial Communication Satisfaction. Illiono State University.

14) Weeden, J. (2015). Capable Couples:Encouraging Healthy Financial Conversations Between Couples.

15) Young, J. E. (2014). Family Communication Patterns,Parental Modeling, \& the Intergenerational Transmission of Confirmation to Romantic Relationships.

16) Zmyslinski-Seelig, A. N. (2016). To Each Their Own:Comparing Satisfaction,Money Management , and Financial Communication across Couple Types. Milwaukee. 